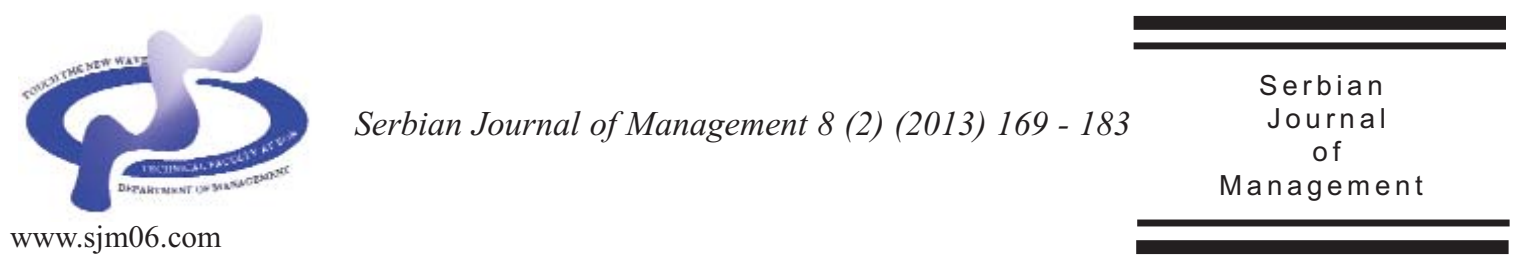

\title{
AN ALTERNATIVE VIEW TO THE TAX EVASION: THE EFFECT OF TAX MORALE ON PAYING TAXES IN MACEDONIA AND EU COUNTRIES
}

\author{
Maja Ristovska ${ }^{a}$, Nikica Mojsoska-Blazevski ${ }^{b^{*}}$ and Miso Nikolov \\ a Laboratory for Labour Market and Social Policy Analysis, \\ University American College-Skopje, Macedonia

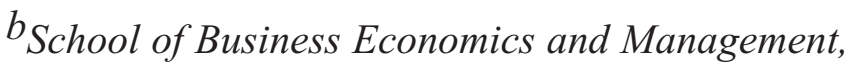 \\ University American College-Skopje, Macedonia
}

(Received 18 April 2013; accepted 13 June 2013)

\begin{abstract}
In the last couple of years there is a growing literature and evidence suggesting that enforcement efforts alone cannot achieve significant increase of tax compliance. This literature links the willingness of citizens to pay taxes with the social values and norms, i.e. to the tax morale. If correct, the optimal government policies to tackle the tax evasion might defer considerably from the common ones.

The aim of this study is therefore to investigate factors that shape the tax morale of Macedonian citizens, and to provide a comparative assessment with the EU countries. Our empirical investigation is based on the work of Frey and Torgler (2007), through estimating an ordered probit model in which the dependent variable is the tax morale, and is regressed on a number of independent variables, age, gender, marital status, education, national pride, trust in institutions, happiness, life satisfaction, etc. Data for our study are from the fourth wave (2008) of the European Values Survey. Our main finding is that contrary to other studies for the European countries, the non-demographic factors are more important factors influencing tax morale in Macedonia than the demographic ones. The main contribution of this study is that it is the first attempt in our knowledge to investigate the factors driving the tax morale in Macedonia.
\end{abstract}

Key words: tax morale, tax evasion, social values and norms, European Values Survey, ordered probit

\section{INTRODUCTION}

Why tax morale is so important for tax compliance policy? Why taxpayers willingly obey the tax policies/rules? Some people are influenced by social norms and feel quilt when underreport their taxable income; others feel obligation to the government and

\footnotetext{
* Corresponding author: nikica@uacs.edu.mk
}

DOI: $10.5937 /$ sjm 8-3776 
authorities and the way they are treated by authorities affects their decision to cooperate on paying taxes. Some individuals are simply predetermined not to evade and they do not even try to find a way to cheat. Others are predisposed tax evaders. However, despite these differences in predisposition to pay taxes based on social and cultural norms, even modern governments rely on the "traditional" enforcement mechanisms. In particular, governments' tax compliance strategies usually rely on enforcement matters applying higher penalties and/or increasing the frequency of audits therefore imposing a method that an individual pays taxes because - and only because - of the economic consequences of detection and punishment. The still prevalent grey economy and tax evasion around the world, including Macedonia, might point to a low effectiveness of this enforcement mechanism. This along with the variety of taxpayers' behaviour raises a need to go beyond the traditional assessment of effectiveness of enforcement mechanisms in answering the tax compliance, and to use an alternative approach to assess the tax morale, i.e. the individuals' decision whether to pay taxes. This alternative approach is based on the behavioural economics.

Therefore the aim of this study is to investigate factors that shape the tax morale of Macedonian citizens, as well as to present a comparative perspective of the factors driving the tax morale in Macedonia, neighboring countries and the EU Member States. We examine the factors influencing tax morale related to the peoples' attitudes towards the society and the basic demographic factors. The main contribution of this study is that it is the first attempt in our knowledge to investigate the factors driving the tax morale in Macedonia.
The structure of this paper is as follows. Section 2 presents a brief literature review on the current studies in the area of the factors that influence tax morale. In section 3, we explain methodology and data used in the study. Section 4 presents the descriptive analysis. Section 5 discusses the results, whereas section 6 contains concluding remarks.

\section{FACTORS THAT INFLUENCE TAX MORALE}

The conventional wisdom is that people pay taxes because of the fear to be caught if evading taxes and the potential penalty. From a theoretical point of view, the behavioural decision model for tax compliance is attributed to Allingham and Sandmo (1972), and is based on the more general Beckerian economics of crime model (Becker, 1968). This model argues that tax compliance depends only on enforcement, given that the declared income is a positive function of the penalty and the probability of being caught. In this respect, increasing the probability of tax audits and/or imposing a large penalty rate in case of evasion would help the government to reduce tax evasion. Following this line of research, other authors developed more complex models of tax compliance (including, for instance, labour supply as a predictor), (see for example, Cowell, 1990; Andreoni et al., 1998; Alm, 1999; Slemrod \& Yitzhaki, 2000). The main conclusions of those studies also focused on the financial incentives for tax evasion, proposing that the latter is to be fought with higher penalties or more frequent tax audits.

However, in reality, the share of taxpayers that undergo a tax audit is relatively low (generally less than 1\%) and rarely the 
punishment is larger than the amount of unpaid taxes (Alm \& Torgler, 2012). Hence, if the conclusions of the Becker's model are applied, we can expect almost everybody to evade taxes, while in the real world the opposite is true: a large share of taxpayers do not consider cheating as an option, even in cases when there are direct economic benefits to them from the cheating (Morelo $\&$ Pujol, 2012). This raises a doubt over the explanatory power of this model; other factors that go beyond the threat of penalty and sanction, into the area of human being's behaviour might better explain individual behaviour in tax compliance decisions. As Buchanan (1995) argues, human behaviour is very complex and, inter alia, influenced by norms "... that act as internal constraints." (p.194). Moreover, the tax culture in a country arises "... by the interaction of the actors and the cultural values like 'honesty', 'justice' or also a 'sense of duty'..." (Nerre, 2008 , p.155). In this regard, the insight on tax morale issue that is used to explain the social values and norms and social and demographic context may provide better explanation of why people willingly conform to paying taxes.

The term "tax morale" here is defined as morale obligation to pay taxes, a belief in contributing to society by paying taxes (Frey $\&$ Torgler, 2007). Tax morale measures individual attitude towards paying taxes, unlike tax evasion that refers to individual behaviour. ${ }^{1}$

Based on the previous studies, we proceed by examining different factors that influence the tax morale in order to gain broader understanding of the issue of tax compliance. In doing so, we also build an argument for assessing the tax morale from an alternative perspective that accounts for the demographic factors, as well as the respondent's values and emotional states. Based on the approach used by Doerrenberg et al. (2010), demographic factors are grouped into: socio-demographic factors/variables and socio-economic factors/variables.

Socio - demographic variables: Empirical studies provide evidence on the link between the tax morale and several individual characteristics, such as age, gender, marital status, religion, religiosity, etc. Based on a study from 17 European countries, Lago-Penas and Lago-Penas (2010) argue that those groups of the population who tend to pay more attention to morality and ethics should have higher tax morale. Those are mainly religious citizens, older people and females. Similarly, Frey and Torgler (2007) show that in the Eastern and Western Europe, older people, women, married people and people with higher church attendance exhibit higher level of tax morale. The literature review of previous studies conducted by Lago-Penas and LagoPenas (2010) shows that age and religiosity are positively and significantly related to the tax morale in all studies, whereas the gender and marital status are not that robust predictors of the tax morale.

Socio-economic variables: Studies that assess the impact of the socio-economic variables on the tax morale usually focus on the educational attainment of an individual, employment status and financial experience (income). There is however no consistency among studies about the significance of these variables, as well as about the sign of the coefficients. Regarding the education, some authors argue that people that are more educated are more likely to get a chance to evade taxes, whereas others find that people that are more educated might be in a better position of recognizing the importance of

\footnotetext{
${ }^{1}$ This tax morale approach is commonly used to explain why people pay taxes, but not why they evade them.
} 
paying taxes for the society, therefore the probability of evading taxes reduces with education (Torgler \& Schneider, 2006; Frey \& Torgler, 2007). Findings are also divergent regarding the income. The underlying assumption in this case is that higher income earners would tend to evade taxes as evasion yields higher returns to higher income earners. Based on European data, Konrad and Qari (2009) do not find evidence that income affects tax morale. On the other hand, Lago-Penas and Lago-Penas (2010) find that tax morale increases with income given that paying taxes when income is high reduces the financial stress. When it comes to the working status, almost all findings indicate that the self-employed tend to have lower tax morale than individuals with other work status (Torgler, 2004; Alm et al., 2006; Frey \& Torgler, 2007; Konrad \& Qari, 2009). Employees might have fewer chances to evade the taxes especially in the systems where taxes are paid by the employers on behalf of the employees, so that they tend to less frequently evade taxes compared to the self-employed.

Trust in government, administration, legal system: Given that taxpayers' behaviour tends to be governed by "rule", stable and easily knowable institutions and trust in those institutions can increase tax morale (Torgler, 2001; Bird et al., 2008). Previous studies add into regression several indicators of trust in government institutions and legal system, such as voice and accountability, political stability and absence of violence, government effectiveness, regulatory quality, rule of law and control of corruption. McGee et al. (2008) found that the strongest argument justifying tax evasion is when the government is corruptive and the tax system unfair. Frey and Torgler (2007) analysed survey data from 30 Western and
Eastern European countries and found a high negative correlation between perceived tax evasion and tax morale. In other words, if an individual perceives that other individuals tend not to pay their taxes, s/he will have lower tax morale. Furthermore, institutional crisis in transition countries in Eastern Europe tend to have a negative effect on tax morale. Trust in legal system is also found to have a significant effect on the tax morale (Torgler, 2001), by increasing the positive feelings of citizens towards paying taxes.

Democracy and national pride: With the introduction of the democracy in the transition countries, taxpayers gained a new decision power (Feld \& Frey, 2002). In such democratic setting, it is assumed that tax revenues are spent according to the taxpayers' preferences therefore increasing the tax morale. Consequently, there might be a relation between the pro-democratic attitude of individuals and the tax morale. Indeed, Lago-Penas and Lago-Penas (2010) find strong positive effect of democracy on the tax morale across 17 European countries. Regarding the national pride, a similar intuition would suggest that taxpayers who are proud of their country of residence might be more willing to pay taxes. Based on a cross-country analysis on several European countries, Konrad and Qari (2009) find strong evidence that patriotism indeed has positive effect on tax morale. Similar results are found for Latin America (Torgler, 2005), Asia (Torgler, 2004) and Russia (Alm et al., 2006). This positive relationship between the national pride and tax morale is also evident across the Eastern Europe or the transition countries (Togler, 2001).

Happiness and satisfaction with the life: Happiness and overall satisfaction with the life might drive higher tax morale. Frey and Stutzer (2002) argue that happiness 
might influence the economic decisions of individuals, such as their consumption, attitudes towards work, investments behaviour, etc. Still, only few studies include happiness as a regressor, such as that of Torgler (2004) for Asia. Tekeli's (2011) study of the determinants of tax morale for Turkey and Japan shows that happiness does not have a statistically significant effect on tax morale.

We proceed by examining data and methodology used in our research.

\section{DATA AND METHODOLOGY}

The analyses on the main factors that drive tax morale in Macedonia is based on survey data provided by European Values Study (EVS), the fourth wave (2008). ${ }^{2}$ The EVS is a European wide investigation on socio-cultural and political change. The survey assesses the basic values and beliefs of people throughout Europe. The entire 2008 sample includes 47 countries. The EVS methodological approach is explained in detail in the European Values Study (2008) source book which provides information on response rates, the sampling procedures, translation of the questionnaire and field work along with measures of coding reliability and data checks. The country survey in Macedonia was distributed to a representative sample of 1,500 individuals.

There are several studies that assess the tax morale for the EU countries, using the EVS dataset (Alm et al., 2006, Frey \& Torgler, 2007, Diego et al., 2011). Our study is based on the methodology used by Frey and Torgler (2007), which estimates an ordered probit model where the dependent variable is the tax morale, which is regressed on a set of independent variables. To estimate the level of tax morale, we would use the following question from the EVS survey:

"Please tell me for each of the following statements whether you think it can always be justified, never been justified or it falls somewhere in between:... Cheating on taxes if you get the chance."

The question leads to a 10-points scale index with two extreme points 1 "never justified" and 10 "always justified". This scale for the purposes of this study has been recoded into four point scale $(0,1,2,3)$, where the value 3 stands for high tax morale - never be justified; value 2 - mid high tax morale; value 1 - mid low tax morale and value 0 - low tax morale in which responses from 4 through 10 where combined into value 0 due to the lack of variance among them.

There is, however, some caution in measuring the tax morale through selfreported morale. In particular, Elffers at al. (1987) found difference between the reported and actual tax evasion. Moreover, as Andreoni et al. (1998) warns, respondents might tend to report higher degree of compliance than the real one, especially those persons that have been involved in tax evasion practices in the past. We expect in our study that the level of honesty is higher as the question of interest does not refer to whether person has evaded taxes but whether cheating on taxes is justified or not, if a person gets a chance to cheat. A concern might also be raised over the use of singleitem measures (i.e. single question) of complex, multidimensional attitude structures, as is the tax morale. However, the use of such single-item measures "... has the advantage of reducing problems of index construction complexity, especially as regards measurement procedure or low

\footnotetext{
2 Data can be downloaded from: http://www.europeanvaluesstudy.eu/evs/data-and-downloads/.
} 
correlation between items." (Torgler \& Schneider, 2007, p.14). Moreover, some studies found similar results when using both single-item measures and laboratory experiments (see, for example, Cummings et al., 2005; Alm \& Torgler, 2006).

Since the dependent variable is ordered categorical variable, we apply an ordered probit regression. Within the regression, it is assumed that a latent and continuous measure of the dependent variable $\mathrm{S}_{\mathrm{i}}{ }^{*}$ follows the normal distribution with $\mu_{i}$ mean and unitary variance. It is defined as:

$\mathrm{S}_{\mathrm{i}}^{*}=\beta^{*} \mathrm{z}_{\mathrm{i}}+\mathrm{e}_{\mathrm{i}}$

whereby $z_{i}$ is a vector of explanatory variables describing individual socioeconomic and demographic characteristics, as well as individual behaviour, $\beta$ is the vector of parameters to be estimated and $e_{i}$ is the random error. We assume that errors are normally and independently distributed.

Then, the observation mechanism is:

$\mathrm{S}_{\mathrm{i}}=\mathrm{j}$ if $\tau_{\mathrm{j}}-1=\mathrm{S}_{\mathrm{i}}{ }^{*}=\tau_{\mathrm{j}}$,

for $\mathrm{j}=1, \ldots, \mathrm{J}$, where $\mathrm{J}$ is the total number of categories.

Given the constraints $\mathrm{v}_{1}<\tau$ for all $1<\mathrm{m}$ and $\tau_{0}=-\infty$ and $\tau_{\mathrm{j}}=+\infty$, it follows that the observed and coded discrete dependent variable $\mathrm{S}_{\mathrm{i}}$ is determined from the model as follows:

$$
S i=\left\{\begin{array}{llc}
1 & \text { if } & -\infty \leq S_{i}^{*} \leq \tau_{1} \\
2 & \text { if } & \tau_{1} \leq S_{i}^{*} \leq \tau_{2} \\
\cdots & & \\
10 & \text { if } & \tau_{9} \leq S_{i}^{*} \leq+\infty
\end{array}\right.
$$

where $\tau_{\mathrm{i}}$, for $\mathrm{i}=1, \ldots, \mathrm{J}$, represents thresholds to be estimated along with the parameter vector $\beta$.

The probability for each category is given by:

$$
\operatorname{Pr}\left(S_{i}=j\right)=\phi\left(\tau_{j} \mid \mu_{i}\right)-\phi\left(\tau_{j-1} \mid \mu_{i}\right),
$$

with $j=1, \ldots, J$.

where, $\phi\left(\mu_{1}\right)$ is the cumulative distribution function for the normal distribution with mean $\mu_{\mathrm{r}}$ and unit variance. To measure the quantitative effect of this variable we calculate the marginal effects because the equation is nonlinear. The marginal effect indicates the change in the percentage or probability of taxpayers having a specific level of tax morale when the independent variable increases by one unit. For the simplicity, the marginal effects in all estimations are presented for the highest value of tax morale only. Furthermore, the answers such as "don't know" and missing values are eliminated in all estimations. The variables used in the study are sociodemographic variables: gender, nationality, age, marital status, religion and religiosity; socio-economic variables: education, employment status, monthly income level; social attitudes and beliefs: national pride, trust in people, trust in government, trust in justice system, trust in civil service, democracy, satisfaction with life and happiness. STATA software has been used for the purposes of the analysis.

\section{DESCRIPTIVE ANALYSIS}

The general demographic characteristics for our sample show that the average age of the respondents is 44 years. The share of males in the sample is $56 \%$, and almost $60 \%$ 
of the respondents are married. Majority of the respondents are from the Christian religion $(80 \%)$. Individuals with completed secondary education dominate in the sample with a share of $57 \%$. Regarding the economic status, $37 \%$ of the individuals in our sample are employed (wage employment), $3.5 \%$ are self-employed, $27 \%$ are unemployed and the rest are inactive people (students, pensioners, housewives). Majority of the respondents have income below 15,550 MKD (45\%), 29\% have income between 15,550 and 27,805 MKD, $19 \%$ have income between 27,806 and 46,000 MKD and 7\% have income above 46,000 MKD.

Frequencies of responses of individuals in the country stating that tax morale is never justifiable, differentiated by socio-economic groups, personal characteristics and attitudes are presented in Tables A1 and A2 (Appendix A). Based on the data, about 81\% of interviewed individuals in Macedonia reported that the "tax morale is never justifiable". A comparison of the frequencies of the responses on tax morale by gender shows that the most frequent response for both groups is "never justifiable option". Regarding the age, descriptive statistics show that the frequency of the "never justifiable" response increases with the age. Full-time employed are strongly against tax cheating compared to the self-employed. The tax morale is increasing with the education level; an exception is individuals with no education of which $95 \%$ reported high tax morale. Individuals earning higher income are more strongly against tax cheating compared to low-income citizens. Married people and widowed more frequently have negative perception towards cheating than the divorced and those never married. About $96 \%$ of the respondents from Southeast region in Macedonia reported highest tax morale. The lowest share of "never justifiable" responses is found in Polog and Southwest region, of $57 \%$ and $44 \%$, respectively. Whereas $90 \%$ of the individuals from Christian religion reported high tax morale, that is the case for $45 \%$ of the respondents from Muslim or other religion. In addition, $90 \%$ of the respondents that hold the Macedonian language as the language of the interview reported high tax morale, whereas this is the case for $33 \%$ of the Albanian language interviews. People who occasionally attend religious services are strongly against tax cheating compared to the more religious people. More than half of the respondents attend religious services only on special holy days and occasions. Tax morale is slightly higher for people who trust the other people. Individuals who trust more the government and justice system have higher tax morale. People who are not confident and do not trust the civil service are more strongly against tax cheating than those who put more trust in civil service. The strongest opposition to tax cheating is found among individuals who are proud of their country and those with more pro-democratic belief. Happiness and satisfaction with life are negatively related to the tax morale.

The next section proceeds with an investigation of the results from the estimated model.

\section{RESULTS AND DISCUSSIONS}

Table B1 (Appendix B) presents main findings from the equation (1). The coefficient of determination shows that independent variables explain about $28 \%$ of the variability of the tax morale. This implies that some other factors than those included in 
the study also have an influence on the tax morale of Macedonian citizens, which is worth of further exploration conditional upon data availability. Coefficients are all jointly significant. The individual significance is found for several variables, that are: age, language spoken by the interviewed person (approximation for the ethnicity), income level, national pride, trust in government, trust in justice, trust in civil service, satisfaction with life and view of the individual effort. All coefficients have the expected signs as predicted by the previous studies, with an exception of the coefficient of the trust in civil service.

The findings for Macedonia differ slightly from those of the other studies for the European countries. In particular, while in section 2 we argued that gender, age and marital status are found significant in all studies of tax morale within the European countries, in Macedonia only the age of an individual has an impact on the tax morale. Similarly, out of all socio-economic variables, only income affects the tax morale of Macedonian citizens; educational attainment and economic (labour market) status do not have a significant impact on tax morale. This is contrary to the findings for other countries, for instance the findings of Lago-Penas and Lago-Penas (2010). On the other hand, most of the variables measuring the effect of trust (in government, judicial system and civil service) on the tax morale are significant. This is in line with the previous findings of Torgler (2001), Frey and Torgler (2007), Bird et al. (2008), McGee et al. (2008), etc. Pride and satisfaction with life are important determinants of the tax morale in Macedonia, as was found for other countries (for instance, in Frey \& Stutzer, 2002; Torgler, 2004; Torgler, 2005; Alm et al., 2006; Konrad \& Qari, 2009).
The analysis of the size of the coefficients is related to the marginal effects of the highest value of tax morale. There is no clear evidence that tax morale increases with the age since coefficients are insignificant for 30-39 age group and 40-49 age group. The results indicate that tax morale in the 50-59 age group is higher than in the reference age group. The proportion of persons of the age group 50-59 who report the highest tax morale is 9 percentage points (p.p) higher than for the reference age group. Our findings also show that, all other things being equal, being from ethnic Macedonian origin (i.e. who speak Macedonian) increases the probability of reporting the highest tax morale by 60 p.p. (compared to other ethnicities), which is rather a strong effect. Tax morale also increases with the income. For instance, the proportion of individuals having income between 27,806 MKD and 46,000 MKD who report highest tax morale is 9.3 p.p. higher than the proportion of individuals with income of below 15,550 MKD who report highest tax morale. The difference in marginal effects in the highest income group is slightly smaller than in the 27,805-46,001 MKD group. The results also indicate a negative relationship between the tax moral and trust in civil service, such that citizens with higher trust in civil service report lower tax morale. The possible explanation for the negative relationship between the tax morale and the trust in civil service can be related to the view that although the civil service can be trustful, taxpayers money are not spend in the most effective way (Gummings et al., 2005).

Similarly, the proportion of citizens who are very proud of their state who report the highest tax morale is 11 p.p. higher than the proportion of citizens who are not proud of their state and report highest tax morale. 
Being satisfied with the life increases the probability of reporting the highest tax morale by 1.1 p.p. compared to individuals that are not satisfied with the life.

\section{CONCLUSION}

This paper used an alternative approach to investigating the factors that influence the tax morale. The methodological approach was based on the previous studies that assess factors that determine the tax morale of individuals. We find that contrary to the other studies across the European countries, the demographic factors in Macedonia play very little role in shaping the tax morale. The exceptions are age of an individual, ethnicity (i.e. language of interview) and income. Gender, marital status, labour market status and education are not exercising significant effect on the tax morale in Macedonia. The results also indicate that there is no significant correlation between a prodemocracy attitude and tax morale. On the other hand, there is a strong effect of factors related to the trust in government institutions, judicial system and in the civil service, national pride and satisfaction with life on the tax morale.

These findings can be used by the tax policy for formulating more effective policies to reducing the tax evasion in the country. In particular, we provide some evidence that increasing the tax morale (and potentially reducing the tax evasion) cannot be solely tackled with more frequent tax inspections and penalties, i.e. enforcement mechanisms. On contrary, policymakers might consider enhancing/building the national pride and increasing the trust in government institutions and judicial system as alternative, effective measures for higher tax morale.
There are some methodological and practical shortcomings of this study. Methodologically, there might be some concern over using a single item/question for measuring complex social phenomena, as the tax morale is. From practical perspective, the actual payment of taxes (or tax evasion) of an individual might differ from the (reported) tax morale. This raises a need for additional research in the area of factors that influence payment/evasion of taxes.

\section{References}

Allingham, M.G., \& Sandmo, A. (1972). Income tax evasion: A Theoretical analysis. Journal of Public Economics, 1(3-4): 323338.

Alm, J., Sanchez, I., \& de Juan, A. (1995). Economic and noneconomic factors in tax compliance. Kyklos, 48(1): 3-18.

Alm, J. (1999). Tax compliance and administration. Pp. 741-768 in W.B. Hildreth \& J.A. Richardson (Eds.), Handbook on Taxation. New York: Marcel Dekker.

Alm, J., Martinez-Vazque, J., \& Torgler, B. (2006). Russian attitudes toward paying taxes - Before, during, and after the transition. International Journal of Social Economics, 33(12): 832- 857.

Alm, J., \& Torgler, B. (2006). Culture differences and tax morale in the United States and in Europe. Journal of Economic Psychology, 27(2): 224-246.

Alm, J., \& Torgler, B. (2012). Do ethics matter? Tax compliance and morality, Working Papers, No. 1207. Tulane University, Department of Economics.

Andreoni, J., Erard, B., \& Feinstein, J. (1998). Tax compliance. The Journal of Economic Literature, 36: 818-860.

Becker, G.S. (1968). Crime and 


\title{
АЛТЕРНАТИВНИ ПОГЛЕД НА ИЗБЕГАВАЫЕ ПЛАЋАЊА ПОРЕЗА: УТИЦАЈ МОРАЛНИХ НАЗОРА НА ПЛАЋАЊЕ ПОРЕЗА У МАКЕДОНИЈИ И ЗЕМЉАМА ЕУ
}

\author{
Маја Ристовска, Никица Мојсоска-Блажевски и Мишо Николов
}

\section{Извод}

Последњих неколико година све је више литературе која говори у прилог томе да је примена само метода принуде недовољна за пораст плаћања пореза. Литература повезује спремност грађана да плаћају порез са социјалним нормама и вредностима, односно, морала. Уколико се добро одабере, стратегија власти на увећању плаћања пореза грађања, која даје резултате, најчешће не спада у конвенционалне.

Из тог разлога, циљ овог истраживања је истраживање фактора који су од утицаја на порески морал Македонских грађана, као и компаративна анализа са земљама ЕУ. Емиријско истраживање је засновано на истраживању Фреја и Тајлора из 2007. године. Истраживање представља детаљну процену модела чија је зависна величина порески морал, чија је регресиона анализа представљена на већем броју независних варијабли: године, пол, брачни статус, национални понос, поверење у институције, образовање, задовољство животом, итд. Потребни подаци за истраживање су добијени на основу истраживања спроведеног 2008, које је мерило "Европске Вредности" испитаника. Основни резултати истраживања показују да, насупрот резултатима који су добијени за ЕУ земље, у случају земаља ван ЕУ најзначајнији фактори који утичу на порески морал не спадају у групу демографских. Такође, ово је прво истраживање оваквог типа, које се бави пореским моралом, спроведено у Македонији, што даје додатну вредност овом раду.

Кључне речи: Порески морал, Наплата пореза, Друштвене вредности и норме, Истраживање европске вредности

punishment: An economic approach. The Journal of Political Economy, 76: 169-217.

Buchanan, J. M. (1995). Economic science and cultural diversity. Kyklos, 48(2): 193-200.

Cowell, F. (1990). Cheating the government: The economics of evasion. MIT Press, Cambridge, MA dissertation.

Doerrenberg, P., \& Peichl, A. (2010). Progressive taxation and tax morale. IZA Discussion Paper Series, No. 5378.

Everest-Phillips, M. (2009). When do elites pay taxes? Tax morale and statebuilding in developing countries. WIDER Conference on The Role of Elites in
Economic Development, 12-13 June, 2009, Helsinki, Finland.

Feld, L.P., \& Frey, B.S. (2002). Trust breeds trust: How taxpayers are treated. Economics of Governance, 3(2): 87-99.

Frey, B.S., \& Torgler, B. (2007). Tax morale and conditional cooperation. Journal of Comparative Economics, 35(1): 136-159.

Gummings, R.G., Martinez-Vazquez, J., McKee, M., \& Torgler, B. (2005). Effects of tax morale on tax compliance: Experimental and survey evidence. Lettner Program Working Papers, Issue 22. Available from: http://www.isn.ethz.ch/isn/DigitalLibrary/Publications/Detail/?ots591=0c54e3 
b 3 - 1 e 9 c - b e 1 e - 2 c 24 - Public Choice, 19: 143-168.

a 6 a 8 c $7060233 \& \operatorname{lng}=$ en $\&$ id $=30010$.

[Accessed November 15, 2012.]

Konrad, K.A., \& Qari, S. (2009). The last refuge of a scoundrel? Patriotism and tax compliance. IZA Discussion Paper Series, No. 4121.

Lago-Penas, I., \& Lago-Penas, S. (2010). The determinants of tax morale in comparative perspective: Evidence from European countries. European Journal of Political Economy, 26(4): 441-453.

McGee, R.W., Ho, S.S.M., \& Li, A.Y.S. (2008). A comparative study on perceived ethics of tax evasion: Hong Kong vs the United States. Journal of Business Ethics, 77: 147-158.

Morelo, J., \& Pujol, F. (2012). Walking inside the potential tax evaders mind: Tax morale does matter. Journal of Business Ethics, 105: 151-162.

Nerre, B. (2008). Tax culture: A basic concept for tax politics. Economic Analysis \& Policy, 38(1): 153-167.

Bird, R.M., Martinez-Vazquez, J., \& Torgler, B. (2008). Tax effort in developing countries and high income countries: The impact of corruption, voice and accountability. Economic Analysis \& Policy, 38(1): 55-71.

Slemrod, J., \& Yitzhaki, S. (2000). Tax avoidance, evasion, and administration. NBER Working Paper Series, No. 7473.

Tekeli, R. (2011). The determinates of tax morale: The effects of cultural differences and politics. Policy Research Institute (PRI) Discussion Paper Series, No. 11A-10). Available from: http://www.mof.go.jp/pri/research/discussio n_paper/ron225.pdf. [Accessed January 25, 2013].

Torgler, B. (2001). Is evasion never justifiable. Journal of Public Finance and
Torgler, B. (2004). Tax morale in Asian countries. Journal of Asian Economics, 15(2): 237-266.

Torgler, B. (2005). Tax morale in Latin America. Public Choice, 122(1-2): 133-157.

Torgler, B. (2006). The importance of faith: Tax morale and religiosity. Journal of Economic Behavior \& Organization, 61(1): 81-109.

Torgler, B., \& Schneider, F.G. (2006). What shapes attitudes toward paying taxes? Evidence from multicultural European countries. Berkeley Program in Law \& Economics Working Paper Series, No. 190. University of California, Berkeley.

Torgler, B., \& Schneider, F.G. (2007). The impact of tax morale and institutional quality on the shadow economy, CESifo Working Paper, No. 1899. Available from: h t $\mathrm{t} p$ : / / w w w . c e s i f o group.de/portal/page/portal/DocBase_Conte nt/WP/WP-CESifo_Working_Papers/wpc es ifo- $2007 /$ w p - c e s if o- 2007 01/cesifo1_wp1899.pdf. [Accessed March 20, 2013]. 
APPENDIX A

Table A1: Level of tax morale

\begin{tabular}{|c|c|c|}
\hline & Freq & \% \\
\hline Low tax morale & 176 & 12.07 \\
\hline Mid-low tax morale & 48 & 3.29 \\
\hline Mid-high tax morale & 48 & 3.29 \\
\hline High tax morale & 1186 & 81.34 \\
\hline Total & 1458 & 100.00 \\
\hline
\end{tabular}

Table A2: Tax morale by subcategories - Groups that reported high tax morale

\begin{tabular}{|c|c|c|c|c|c|c|c|c|}
\hline \multicolumn{9}{|c|}{ Dependent variable, high tax morale } \\
\hline \multicolumn{9}{|l|}{$\begin{array}{c}\begin{array}{c}\text { Independent } \\
\text { variables }\end{array} \\
\end{array}$} \\
\hline \multirow[t]{3}{*}{ Gender } & Female & Male & & & & & & \\
\hline & 0.858 & 0.779 & & & & & & \\
\hline & -0.35 & -0.415 & & & & & & \\
\hline \multirow[t]{3}{*}{ Nationality } & Albanian & Macedonian & & & & & & \\
\hline & 0.333 & 0.897 & & & & & & \\
\hline & -0.472 & -0.304 & & & & & & \\
\hline \multirow[t]{3}{*}{ Age } & $\begin{array}{c}\text { Less than } 29 \\
\text { y.o }\end{array}$ & 30-39 years old & $\begin{array}{l}\text { 40-49 years } \\
\text { old }\end{array}$ & $\begin{array}{c}\text { 50-59 years } \\
\text { old }\end{array}$ & $\begin{array}{c}\text { More } \\
\text { than } 60 \\
\text { years old }\end{array}$ & & & \\
\hline & 0.746 & 0.808 & 0.78 & 0.87 & 0.883 & & & \\
\hline & -0.436 & -0.395 & -0.415 & -0.337 & -0.322 & & & \\
\hline \multirow[t]{3}{*}{$\begin{array}{c}\text { Marital } \\
\text { status }\end{array}$} & Married & Divorced/Separated & Widowed & $\begin{array}{c}\text { Never } \\
\text { married }\end{array}$ & & & & \\
\hline & 0.829 & 0.783 & 0.896 & 0.762 & & & & \\
\hline & -0.376 & -0.417 & -0.307 & -0.426 & & & & \\
\hline \multirow[t]{3}{*}{ Region } & Vardar & East & Southwest & Southeast & Pelagonia & Polog & Northeast & Skopje \\
\hline & 0.789 & 0.946 & 0.44 & 0.974 & 0.947 & 0.571 & 0.96 & 0.857 \\
\hline & -0.41 & -0.227 & -0.498 & -0.159 & -0.225 & -0.496 & -0.197 & -0.35 \\
\hline \multirow[t]{3}{*}{ Religion } & $\begin{array}{c}\text { Muslim } \\
\text { religion/other }\end{array}$ & Christian religion & & & & & & \\
\hline & 0.457 & 0.904 & & & & & & \\
\hline & -0.499 & -0.295 & & & & & & \\
\hline \multirow[t]{3}{*}{ Religiosity } & $\begin{array}{l}\text { More than } \\
\text { once per } \\
\text { week }\end{array}$ & Once per week & $\begin{array}{l}\text { Once per } \\
\text { month }\end{array}$ & $\begin{array}{c}\text { Only on } \\
\text { special } \\
\text { holidays }\end{array}$ & $\begin{array}{l}\text { Once per } \\
\text { year }\end{array}$ & Rarely & $\begin{array}{c}\text { Never, } \\
\text { almost } \\
\text { never }\end{array}$ & \\
\hline & 0.685 & 0.735 & 0.725 & 0.856 & 0.914 & 0.828 & 0.806 & \\
\hline & -0.468 & -0.443 & -0.448 & -0.352 & -0.282 & -0.378 & -0.397 & \\
\hline \multirow[t]{3}{*}{ Education } & No education & Primary & Secondary & $\begin{array}{c}\text { Higher } \\
\text { education }\end{array}$ & & & & \\
\hline & 0.95 & 0.722 & 0.823 & 0.856 & & & & \\
\hline & -0.224 & -0.449 & -0.382 & -0.351 & & & & \\
\hline \multirow[t]{3}{*}{$\begin{array}{c}\text { Employment } \\
\text { status } \\
\end{array}$} & Paid work & Self-employed & At home & Unemployed & Student & Retired & Other & \\
\hline & 0.858 & 0.62 & 0.721 & 0.765 & 0.802 & 0.877 & 0.571 & \\
\hline & -0.349 & -0.49 & -0.452 & -0.424 & -0.4 & -0.329 & -0.507 & \\
\hline
\end{tabular}




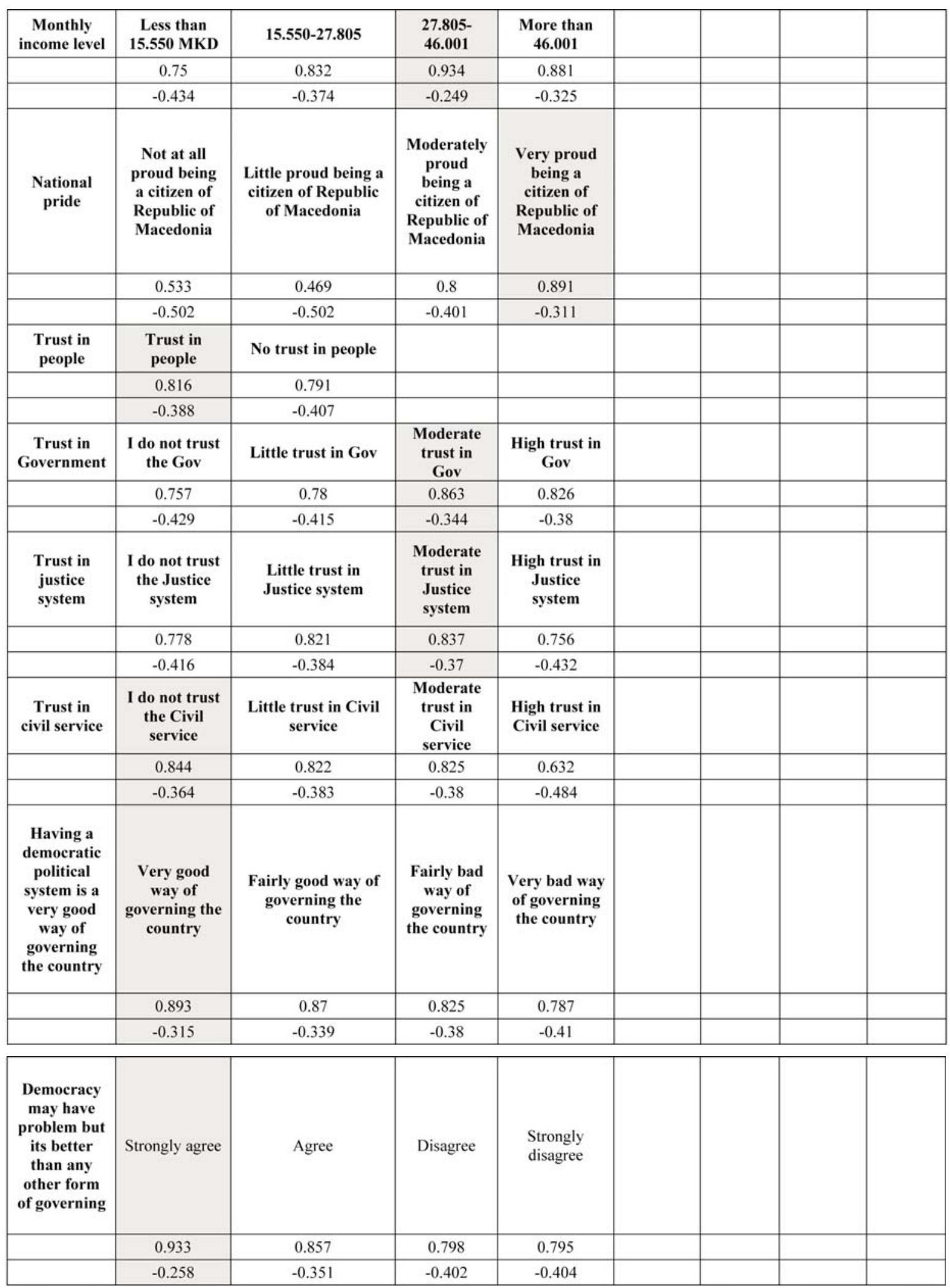




\begin{tabular}{|c|c|c|c|c|c|c|c|c|}
\hline $\begin{array}{c}\text { Satisfied } \\
\text { with the life }\end{array}$ & Unsatisfied & Satisfied & & & & & \\
\hline & 0.631 & 0.794 & & & & & & \\
\hline & -0.486 & -0.406 & & & & & & \\
\hline Happiness & $\begin{array}{c}\text { Not at all } \\
\text { happy }\end{array}$ & Little happy & $\begin{array}{c}\text { Moderate } \\
\text { happy }\end{array}$ & Very happy & & & & \\
\hline & 0.638 & 0.701 & 0.841 & 0.821 & & & & \\
\hline & -0.484 & -0.459 & -0.366 & -0.384 & & & & \\
\hline
\end{tabular}

Note: Frequencies of responses. Standard errors reported in parenthesis. Source of the used data: European Values Study the fourth wave (2008). Available from: http://www.europeanvaluesstudy.eu/evs/data-and-downloads/

\section{APPENDIX B}

\section{Table B1: Estimation results from the ordered probit regression}

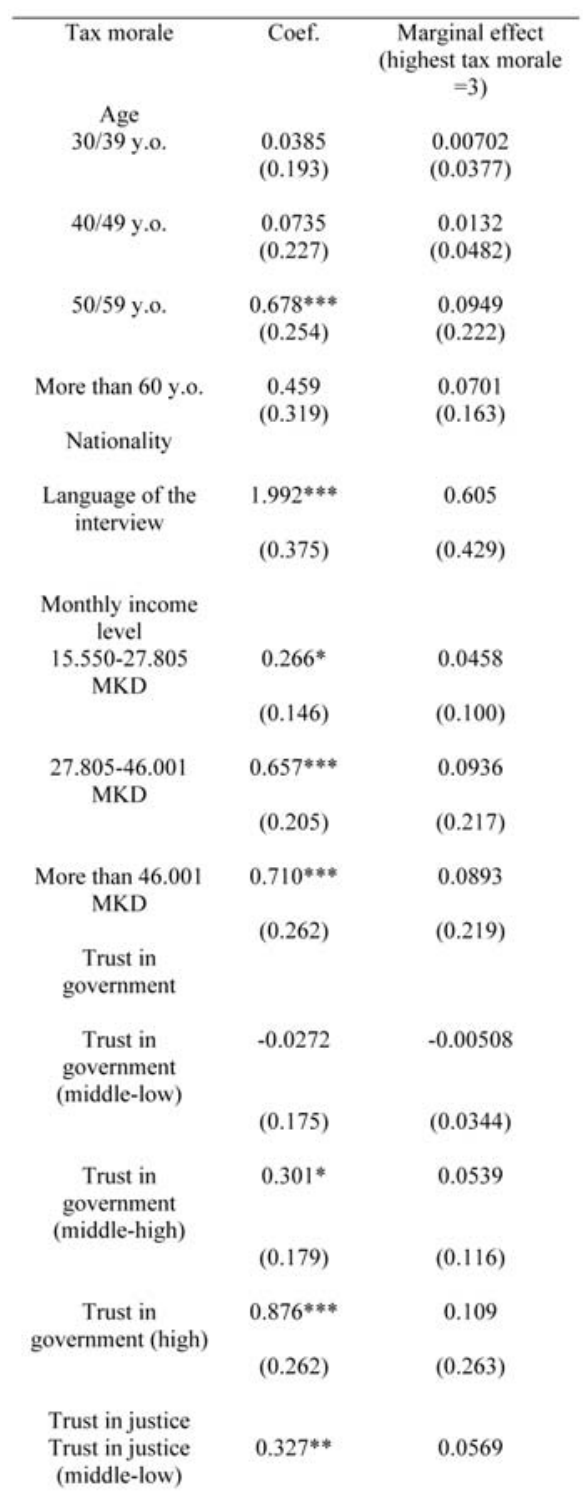




\section{Table B1: Estimation results from the ordered probit regression (continuance)}

\begin{tabular}{|c|c|c|}
\hline & $(0.162)$ & $(0.123)$ \\
\hline \multirow{2}{*}{$\begin{array}{l}\text { Trust in justice } \\
\text { (middle-high) }\end{array}$} & 0.179 & 0.0321 \\
\hline & $(0.184)$ & $(0.0742)$ \\
\hline \multirow{2}{*}{$\begin{array}{l}\text { Trust in justice } \\
\text { (high) }\end{array}$} & 0.170 & 0.0288 \\
\hline & $(0.299)$ & $(0.0773)$ \\
\hline \multirow{2}{*}{$\begin{array}{c}\text { Trust in civil } \\
\text { service (middle- } \\
\text { low) }\end{array}$} & $-0.606 * * *$ & -0.128 \\
\hline & $(0.207)$ & $(0.237)$ \\
\hline \multirow{2}{*}{$\begin{array}{l}\text { Trust in civil } \\
\text { service (middle- } \\
\text { high) }\end{array}$} & $-0.507^{* *}$ & -0.0971 \\
\hline & $(0.218)$ & $(0.196)$ \\
\hline \multirow{2}{*}{$\begin{array}{l}\text { Trust in civil } \\
\text { service (high) }\end{array}$} & $-1.259 * * *$ & -0.373 \\
\hline & $(0.285)$ & $(0.408)$ \\
\hline \multirow{2}{*}{$\begin{array}{l}\text { National Pride } \\
\text { (middle-low) }\end{array}$} & 0.220 & 0.0360 \\
\hline & $(0.294)$ & $(0.0895)$ \\
\hline \multirow{2}{*}{$\begin{array}{l}\text { National Pride } \\
\text { (middle-high) }\end{array}$} & $0.410^{*}$ & 0.0700 \\
\hline & $(0.244)$ & $(0.154)$ \\
\hline \multirow{2}{*}{$\begin{array}{l}\text { National Pride } \\
\text { (high) }\end{array}$} & $0.593^{* *}$ & 0.115 \\
\hline & $(0.245)$ & $(0.228)$ \\
\hline Satisfaction in life & $\begin{array}{l}0.0665^{* *} \\
(0.0261)\end{array}$ & $\begin{array}{c}0.0123 \\
(0.0257)\end{array}$ \\
\hline Observations & 923 & \\
\hline Prob $>$ chi 2 & 0.0000 & \\
\hline Pseudo R2 & 0.2868 & \\
\hline
\end{tabular}

Note: Reported categories which exert statistically significant impact on the dependent variable Depended variable tax morale on a four point scale. In the reference group: female, lower age group (less than 29 years old), married, no education, lower income group (less than 15.550 Macedonian denars); Muslim/other religion, lower level of trust in government, justice, civil service, national pride, democracy1,2, happiness. Standard errors reported in parenthesis. Significance levels are: $* 0.05<\mathrm{p}<0.10, * * 0.01<\mathrm{p}<0.05, * * * \mathrm{p}<0.01$. The marginal effect is calculated at the highest tax morale score. $\mathrm{dy} / \mathrm{dx}$ is for discrete change of dummy variables from 0 to 1 and dy/dx for factor levels is the discrete change from the base level. 